DOI: $10.33876 / 2311-0546 / 2022-1 / 243-263$

(C) Н.А. Белова, А.М. Белов

\title{
МИГРАЦИОННЫЕ ПРОЦЕССЫ И ИХ ВЛИЯНИЕ НА СОЦИАЛЬНО-ЭКОНОМИЧЕСКОЕ РАЗВИТИЕ ЦЕНТРАЛЬНОЙ РОССИИ НА ПРИМЕРЕ КОСТРОМСКОЙ ОБЛАСТИ*
}

В статье представлень результаты всестороннего анализа одного из слаборазвитых регионов Центральной России - Костромской области в 20212. Итоги исследования отражают действительное социально-экономическое положение населения, демографическую ситуацию и межэтническое взаимодействие фактически во всем Центральном федеральном округе. В статье представлен и проанализирован портрет мигранта, то, каким видит его местное население, а также сформулированы основные пожелания к представителям других этносов и конфессий. Авторы статьи предприняли попытку разобраться в причинах настороженного отношения, а также раскрыть основные мигрантские фобии и предубеждения, которые возникли у местных жителей под действием различных факторов. Был проведен сравнительный анализ с предыдущчим опросами, которые были осуществлень в рассматриваемом регионе, начиная с 2014 г.

Итогами проекта стали рекомендаџии для местных и федеральных властей в сфере межэтнического взаимодействия, а также успешной адаптации не только мигрантов, но и местных жителей к новым меняющимся реалиям.

Ключевые слова: Кострома, миграции, мониторинг, трудовые ресурсы, межэтнические отношения

Ссылка при цитировании: Белова Н.А., Белов А.М. Миграционные процессы и их влияние на социально-экономическое развитие Центральной России на примере Костромской области // Вестник антропологии, 2022, № 1. С. 243-263.

DOI: $10.33876 / 2311-0546 / 2022-1 / 243-263$

(C) N.A. Belova, A.M. Belov

\section{THE IMPACT OF MIGRATION ON THE SOCIO- ECONOMIC DEVELOPMENT IN CENTRAL RUSSIA (THE CASE OF THE KOSTROMA REGION)}

The article presents the results of a comprehensive socio-anthropological study carried out in 2021 in the Kostroma region - one of the underdeveloped regions

Белова Наталья Андреевна - к.и.н., научный сотрудник, Институт этнологии и антропологии РАН (119334, Москва, Ленинский пр. 32а)

Белов Андрей Михайлович - д.и.н., профессор, Костромской государственный университет (156005, г. Кострома, ул. Дзержинского, д. 17). Эл. почта: belovi_1957@mail.ru

* Выполнено в ходе реализации научно-исследовательского проекта РФФИ № 21-011-31820. 
of Central Russia. The study results accurately reflect the socio-economic and demographic situation of the Kostroma people and interethnic communication in small towns and settlements with a predominately Russian population. The Kostroma case, according to the authors, is typical for the entire Central Federal District. The article portrays a migrant as seen by local residents and voices the requests of the Russians to the migrants from different ethnic and religious groups, which were expressed in the surveys. The authors explored the reasons for the wariness of the local population towards new residents and sought to determine what supports their positive perception of each other and what provokes anti-migrant phobias and prejudices. The comparative analysis of new data compared with the previous surveys in the region since 2014 provided insight into the dynamics of the ongoing processes. The final section of the article suggests recommendations for local and federal authorities aimed at more successful adaptation not only of migrants but also of local residents to the new changing realities.

Keywords: Kostroma, migration, monitoring, labor resources, interethnic relations, labor migrants

For Citation: Belova N.A., and A.M. Belov. 2022. The Impact of Migration on the Socio-Economic Development in Central Russia (the Case of the Kostroma Region). Herald of Anthropology (Vestnik Antropologii) 1: 243-263.

Author Info: Belova, Natalia A. - PhD in hist., Institute of Ethnology and Antropology RAS (Moscow, Russia). E-mail: belovanatalia86@gmail.com.

Belov, Andrey M. - Doctor of Hist., Professor, Kostroma State University (Kostroma, Russia). E-mail: belovi_1957@mail.ru.

Funding: The research was carried out within the framework of the Russian Foundation for Basic Research. Project No. 21-011-31820 OPN "Migration processes and their impact on the socio-economic development of Central Russia: comparative analysis of the province and megalopolis (the case of the Kostroma region and Moscow)".

Актуальность исследования определяется кризисным состоянием регионов Центральной России как экономического, так и социально-демографического характера. Экономическая ситуация здесь усугубляется из-за растущего внешнего давления на Россию стран Западной Европы и США, вызванного затянувшимся конфликтом на Украине, санкциями, обусловленными позицией России по событиям в Беларуси и Казахстане. В 2020 г. ухудшилась общемировая обстановка еще из-за пандемии Covid-19 и связанных с ней ограничительных мер, своего рода «локдаунов», отрицательно отразившихся на экономике страны. По словам СМИ, это было «беспрецедентной остановкой деловой активности ради борьбы с пандемией, обвалом цен на нефть и падением спроса на экспорт» (Старостина 2020). Перечисленные факторы очень сильно сказываются в первую очередь на слаборазвитых и дотационных регионах, на благосостоянии и благополучии жителей Центральной России, приводя к оттоку простых россиян (и в большей степени молодой его части) из провинции, в т.ч. из Костромской и ряда сопредельных областей Нечерноземья (Ивановской, Владимирской) в столицы или более развитые промышленные центры - Ярославль, 
Екатеринбург и др. Отрицательная динамика по многим социально-экономическим параметрам характерна для Центральной России на протяжении уже нескольких десятилетий, чему есть ряд исторических объяснений.

Многие тенденции миграции закладывались еще в конце прошлого ХХ века и связаны с радикальными рыночными реформами 1990-х гг. Если говорить о Костромской области, в результате перехода к свободному перемещению капиталов, с открытием внутренних рынков для дешевых импортных товаров пришла в упадок являвшаяся местной исторической специализацией вся текстильная промышленность региона. Оказались невостребованными десятки тысяч рабочих и специалистов, трудившихся в легкой промышленности Костромской области. Отток населения в поисках работы и его естественная убыль привели к сокращению числа жителей за последние 30 лет более чем на 200 тыс. человек или на четверть от их общего количества. Еще одним результатом упадка экономики стало отсутствие поддержки государством сельского хозяйства в условиях рыночных реформ, что привело в ситуации географического расположения в критической климатической зоне к ликвидации десятков колхозов и совхозов, а вместе с ними и сотен сел и деревень Костромской области. Без дополнительных рабочих рук и выравнивания демографической структуры населения за счет миграции, невозможно создание благоприятных экономических условий для развития региона. Поэтому внешняя миграция может рассматриваться как определенный способ разрешения проблемы депопуляции в Костромской области. Однако приток мигрантов несет сложности в сфере межэтнического взаимодействия и создает определенную напряженность между приезжими и местным населением, что обусловливает актуальность и необходимость изучения проблемы взаимоотношений мигрантов и местных жителей не только в столичных регионах, но и в провинции.

Научные исследования миграционных процессов перспективны, т.к. созданные на основе полученных данных методики и рекомендации позволяют, на наш взгляд, выработать новый подход к устранению демографических проблем. Изучать ситуацию необходимо комплексно, используя разнообразные источники и материалы, включая такие методы, как разработанный ведущими научными сотрудниками ИЭА РАН этнологический мониторинг, мониторинг контента СМИ, анализ статистических данных, социологические опросы в сочетании с экспертными интервью и т.д. В этой связи кросс-исторические исследования социальных антропологов и историков представляют особую не только научную, но и общественную значимость.

Основная цель этого исследования - выявить истоки демографического кризиса в регионах Центральной России, а также показать причины и последствия трудовой миграции, изучить потенциал использования труда представителей ближнего и дальнего зарубежья в различных отраслях народного хозяйства Костромской области, а также выработать ряд методических и практических рекомендаций для профилактики межэтнических проблем в регионе. Эта цель была решена путем применения комплекса методик (составление опроса, экспертные интервью, контент-анализ, сравнительный и исторический анализ и др.).

Изучение межэтнической ситуации в Центральной России представляет особую важность, поскольку в современном общественном и научном дискурсе сложилось мнение, что в центральных регионах отношения между этносами дружественны ввиду того, что доля русского населения в этих областях превалирует (как правило более 95\%), и поэтому уровень ксенофобии стремится к нулю, а в обществе царит толерант- 
ность и взаимное согласие, солидарность и терпимость. К слову, это же мнение активно поддерживается и местными властями. Наши исследования выявляют совершенно иную картину. Например, полевые материалы, собранные в 2020 г, показали, что местные жители понимают важность труда мигрантов и видят его необходимость. Но в целом дружелюбия и толерантности от осознания потребности региона в иностранных мигрантах пока нет. Ситуация скорее напоминает латентный конфликт, который в случае резонансного происшествия может вылиться в межэтническую потасовку под лозунгом «Бей чужих». Даже признанные эксперты в социальных вопросах не отличаются должной терпимостью: «Мигранты зарабатывают очень и очень неплохо, около 17 тыс., а я получаю около 20 тыс. руб. С чего это им такие зарплаты платить надо?» (жен., 32 г.). «У меня есть друг мигрант-азербайджанец. Живет в Костроме 40 лет, уважаемый человек» (муж., 35 лет); «Я нормально их воспринимаю», - А если дочка за таджика замуж соберется? (Н.Б.) - Шутишь что ли. Не дай Бог» (ПМА 2018). События, которые происходят в регионах время от времени, подтверждают наши выводы. Например, в 2012 г. в г. Нерехта Костромской области из-за «поножовщины» сформировалась угроза межнационального конфликта между местным населением и приезжими, тем самым подтвердилась неготовность жителей провинции, особенно малых городов к приезду представителей других народов.

\section{Краткий историографический обзор}

Изучение проблем миграции началось еще в XIX в. и не теряет своей научной значимости до сих пор. На сегодняшний день масштаб глобализации и интеграции общества делают процесс перемещения населения одним из ключевых в мире. Поэтому разные отрасли современной науки уделяют большое внимание всестороннему изучению миграции и миграционных процессов. Исследование проблем миграции и адаптации мигрантов отечественными учеными было предопределено ходом исторического процесса. В советское время мобильность населения стала высокой в результате индустриализации, урбанизации, образования колхозов и позже их преобразования в государственные сельскохозяйственные предприятия, а после распада СССР и образования РФ миграционная подвижность возросла в связи с обострением социально-политической ситуации, экономическим кризисом, экологическими катастрофами, расширением зоны межэтнических конфликтов.

Большинство работ, посвященных миграции, представляют собой социально-демографические, экономико-статистические, экономико-географические или социологические исследования. Отдельные стороны миграции населения, в частности, вопросы миграции как способа перераспределения трудовых ресурсов, освещались в исследованиях В.А. Болдырева, М.В. Дарагана, О.В. Лармина, И.С. Масловой, Е.Н. Рузавиной, Е.С. Русанова, М.Я. Сонина, Е.А. Янковской, Н. Величко и других. Они обращали особое внимание на сущность экономических и социально-демографических предпосылок, определяющих и формирующих условия перераспределения рабочих кадров, на вопросы о соотношении объективных и субъективных факторов, сознательного и стихийного в демографических процессах, на экономическую обусловленность форм и направлений миграции. В работах вышеуказанных авторов была предпринята попытка раскрыть специфику механизма перераспределения рабочей силы в единстве его объективных и субъективных сторон, обосновать необходимые направления его 
совершенствования с учетом требований развития экономики, особенностей демографической ситуации и достигнутого уровня занятости трудоспособного населения в народном хозяйстве, характерном для социалистического общества.

С начала 1990-х годов начался новый этап в исследовании адаптации мигрантов, теперь уже в постсоветском пространстве. Новые явления в миграционных потоках, связанные с появлением массовых переселенцев и беженцев, нуждались в совершенно ином подходе к миграционной ситуации в России с акцентом на анализ факторов адаптации новых жителей. Социально-политические особенности миграционных процессов нашли отражение в работах Г.Г. Гольдина, Г.Ф. Морозовой, А.Г. Осипова, Л.Л. Рыбаковского, А.Х. Поповой и др. Постепенно появились обобщающие исследования. Г.С. Витковская предложила классификацию факторов внутренней миграции. Проблемы адаптации вынужденных мигрантов в Центральной России исследовались Т.Д. Ивановой, Ж.А. Зайончковской, Ф.С. Холбобоевым и другими авторами. Особый интерес для разработки социологической теории адаптации мигрантов представляют работы Л.В. Макаровой, Г.Ф. Морозовой, Л.Л. Рыбаковского, Н.В. Тарасовой, В.Д. Шапиро. Новые информационные парадигмы, отражающие меняющуюся роль информации в миграционных процессах, освещаются в трудах Н.Р. Маликовой.

Усиливается интерес к проблемам управления миграцией. Становится все более очевидным, что задача заключается не только в том, чтобы прогнозировать масштабы миграции, хотя и необходимо знать параметры миграционной подвижности трудовых ресурсов как по стране в целом, так и по отдельным экономическим регионам, но значительно важнее то, в каких направлениях осуществляются миграции населения, соответствуют ли эти направления интересам общества на данном этапе его развития. Иначе говоря, для устранения негативных элементов в миграции необходимо изучение механизма управления миграцией. Эти вопросы нашли свое отражение в публикациях О.Д. Воробьевой, Т.М. Регент, И.А. Романова, М.Л. Тюркина.

В работах 2000-х годов значительное место уделено проблеме социокультурной адаптации переселенцев в иноэтнической среде. Эту проблематика исследуется в работах В.А. Тишкова, В.В. Амелина, В.В. Степанова, М.Ю. Мартыновой, И.М. Бадыштовой, С.В. Барановой, В.В. Гриценко, А.В. Дмитриевой, Г.Е. Зборовского, Е.А. Назаровой и других авторов. Анализу миграции как вида трудовой мобильности в современном российском обществе посвящен ряд работ В.С. Белозерова, С.В. Рязанцева, А.Н. Попова, Н.Н. Суворовой и др. Методологическую базу теории адаптации мигрантов значительно усиливают работы по социологии миграции.

Несомненный вклад в разработку и изучение проблем миграции и адаптации мигрантов в российское общество внесли ученые ИЭА РАН и эксперты сети EAWARN, которые на протяжении нескольких десятилетий занимались изучением межэтнических конфликтов, являются экспертами и ведущими консультантами федеральных органов власти, принимающие работу в создании законов и разработке мер по профилактике экстремизма и ксенофобии (В.А. Тишков, М.Ю. Мартынова, В.Ю. Зорин, В.В. Степанов, М.Н. Губогло, О.В. Кульбачевская и др.).

Наше исследование является продолжением работ ИЭА РАН с использованием новых методик, которые были успешно апробированы в ходе реализации этого проекта для выявления особенностей адаптации мигрантов, причин роста ксенофобии, а также анализа социально-экономических последствий пандемии. Изучение ситуации в Центральной России всегда актуально, поскольку это исторический центр 
страны, с многовековой историей и традицией, который впервые за много лет нуждается в сохранении и восстановлении.

\section{Современная экономическая ситуация в регионе}

Костромской области в 2022 г. исполняется 78 лет. Экспертами область оценивается как депрессивная, слаборазвитая, с одной из самых сильных депопуляцией населения в стране. Начиная с 1989 г. численность жителей сократилась с 804,3 до 628,4 тыс. чел. (на 22\% или на 176 тыс. чел.) ${ }^{1}$. И основная причина оттока населения и низкой рождаемости заключается в неразвитой промышленности, в отсутствии рабочих мест, упадке сельского хозяйства, а также низком уровне и качестве жизни в сельской местности. По прогнозам РОССТАТА население РФ сократится к 2036 г. на 3,5 млн (3 656865 чел.). Соответственно такие регионы, как Костромская область первыми попадут под удар, потому что последние 30 лет в демографическом плане мы наблюдаем здесь весьма тяжелую картину. Естественная убыль населения происходит с 1990 года, согласно статистическим отчетам Костромской службы статистики население области за пол века сократилось на четверть. Уже сейчас многие деревни заброшены жителями (Костромская область занимает 5 место в стране по количеству заброшенных деревень, которые уже вряд ли смогут возродиться). Сельское население переезжает в города не только потому, что отсутствует возможность достойного заработка, но и в силу полного уничтожения социальной инфраструктуры - детям негде учиться, у стариков нет возможности посещать врачей, а взрослое население не может найти достойную работу. Разброс среднего заработка по области в 2014 г. составил от 7 тыс. руб. до 30 тыс. руб. в месяц. Утяжеляют ситуацию существующие проблемы в социальной сфере и здравоохранении, а также полное отсутствие жилищной инфраструктуры.

Вместе с тем по нашим наблюдениям официальные органы власти стараются скрыть ухудшение ситуации в регионе. Согласно отчету губернатора, в 2019 году Костромская область по целому ряду показателей развития вышла на относительно хороший уровень:

- 22-е место по темпам роста собственных доходов бюджета;

- $\quad$ 18-е место по уровню организации общего образования;

- 5-е место в рейтинге по отрасли «Культура».

По словам руководителя региона, за 2019 год значительно, до 90\% к собственным доходам, сокращён государственный долг Костромской области. Сейчас госдолг региона - чуть более $80 \%{ }^{2}$, в 2017 году он составлял $143 \%$. Таких результатов удалось достичь благодаря росту собственных доходов бюджета Костромской области. При этом ни одна социальная программа не была сокращена, сообщает губернатор. Но совокупный анализ других источников показывает иную картину. Например, депутат Костромской областной Думы и бизнесмен Владимир Михайлов говорит в одном из интервью следующее:

«Финансовые проблемы не позволяют выполнять все социальные обяза-

\footnotetext{
${ }^{1}$ См.: Росстат. Всероссийская перепись населения 2010 г.; Костромская область в цифрах. Стат. сб. / Костромастат. - К., 2021. - 117c. kostroma.gks.ru.

${ }^{2}$ Напомним, что в 2018 г. было введено внешнее экономическое сопровождение федеральными органами власти - казначейством, поскольку долг Костромской области стал равен годовому бюджету перед государством, а по размеру гос. долга область находится на втором месте среди всех регионов РФ.
} 
тельства. В области более 700 детей-сирот, достигших 18-летнего возраста, не могут получить жилье, даже если выигрывают суды. Региональные власти не поддерживают существующие предприятия, а делают ставку на приходящих инвесторов. Но создание льгот и преференций для новых производств создает неконкурентные условия для предприятий, которые уже здесь работают. У меня иногда возникает ощущение, что взят курс на развал еще оставшейся промышленности» (Кузнецов, Уханков 2019).

Неудовлетворительное состояние социальных программ подтверждают и наши полевые данные. Например, многодетные семьи фактически лишились своих льгот в Костроме и могут рассчитывать лишь на федеральную поддержку. Их посещение в музеи, театры, выставки идет по базовой ставке. Ряд льгот были «монетизированы» местными властями. В частности, для компенсации коммунальных услуг, проезда, лекарств и питания в школе многодетная семья должна быть признана малоимущей. Чтобы получить этот статус, многодетной маме (а чаще именно женщинам приходится этим заниматься) понадобится собрать 20 видов различных документов. В материальном эквиваленте сумма компенсации составляет около 2 тыс. в месяц, если дети достигли 3-х летнего возраста. Компенсация коммунальных услуг насчитывает 200 рублей на человека (1 тыс. рублей в месяц), тогда как суммарно за коммунальные услуги в Костроме ежемесячно приходится около 8-9 тыс. руб. за квартиру 64 м². Для семьи, которая платит ипотеку, эта сумма считается ничтожно маленькой и выглядит в глазах действительно нуждающихся семей скорее издевательством, чем реальной помощью.

Другой проблемой в регионе остается медленная газификация. Во время своего визита в 2020 г. в Костромскую область это же отметил премьер М.В. Мишустин: «Достаточно медленно идет газификация населенных пунктов. XXI век, центр России, а люди живут без газа <... Получается, что регион с богатейшей историей, хорошим инвестиционным потенциалом по-прежнему пользуется канализацией советских времен, а люди вынуждены лечиться в больнице, построенной еще при царе-батюшке без элементарных удобств» (Мимустин 2020).

В мае 2021 г. в СМИ прошла новость о том, что жители Островского района написали президенту письмо с просьбой провести им газ. Документ опубликовали в группе «ДТП Кострома»:

В Островском проживает более 5 тысяч человек, а в самом районе более 12 тысяч человек. Из-за отсутствия газа расходы на отопление и горячее водоснабжение объектов социальной сферы и ЖКХ отнимают большую долю бюджета нашей семьи. Отсутствие в Островском районе газификации не дает возможности населению комфортно жить. Молодежь уезжает из Островского района и Костромской области, так как нет достойных условий для работы и жизни здесь. Почти у всех жителей района печное отопление, зимой топить печь нужно 2 раза в день. В домах, которые отапливаются дровами и опилками, население тратит существенные денежные средства, а именно более $50 \%$ от зарплат и пенсий (Жители 2021).

Область газифицирована только на $62 \%$, что учитывает лишь крупные города и центры. Газификация идет очень медленно, и этот процесс начался относительно недавно. По отчетам видно, что основная программа по газификации области стартовала всего 10 лет назад, когда в 2011 г. здесь приступили к строительству газопро- 
вода-отвода «Галич - Мантурово - Шарья» общей протяженностью 182 км (Газификация 2021). Согласно принятому 1 июня 2021 г. закону, газ должны довести до территории домового владения, а подключение и проведение его по участку и в дом придется оплатить хозяину домовладения. Ориентировочная стоимость подключения на сегодня составляет 100-150,0 тыс. руб. (там же). Для организации газоснабжения в доме необходимо разработать проект внутреннего газопровода, для этого обязательно получение технических условий на подключение к газу. С заказчиком согласовывается трассировка газопровода по участку. Лишь после утверждения проекта разрешается осуществлять строительство системы газопровода (Блохин 2021).

Для решения и облегчения процесса газификации домов костромские депутаты выступили с инициативой разрешить использование материнского капитала на газификацию жилья. «Подключение дома к природному газу можно расценивать как улучшение жилищных условий семьи. При переводе с печного на индивидуальное газовое отопление значительно уменьшаются расходы на топливо. Кроме того, у семьи появляется дополнительная коммунальная услуга - горячее водоснабжение», говорится в источнике (Костромские депутаты 2021). Кроме этого в Костромской области действуют меры поддержки на оплату внутридомовой газификации для пенсионеров, малоимущих семей и одиноких граждан.

Мониторинг форумов, сообществ в социальных сетях, где обсуждают и оставляют комментарии к новостям по проекту газопровода местные жители (описание и ссылки см. ниже) ${ }^{1}$, доказывает, что многие из них отчаялись получить долгожданное тепло в дома, поэтому повсеместно ведутся споры, действительно ли будет газ или все же это очередные обещания властей, особенно в рамках предвыборной кампании (выборы были осенью 2021 г.). Споры доходят в комментариях до ругательств. Но главный вопрос, который интересует большинство - это финансовые затраты (на сегодняшний день уже около 200 тыс.), к которым приведет установка газа. Для жителей сельской местности это серьезные суммы, которые необходимо брать в кредит под более высокие проценты, чем в ипотеку. Вот примерные комментарии:

М.А.: «А подключение будет в ипотеку?»;

Г.И.: «Все уравновесится, дешевле не будет»;

P.Р.: «Подключат пару домов бесплатно, а остальным за деньги предложат...»;

Д.О.: «Лучше бы не писали. А в других районах людей нет что ли?»;

Б.Н.: «А Поназырево даже в плане нет. Мы наверное и не Костромская область?» ${ }^{2}$.

Эти комментарии доказывают, что проблема стоит весьма остро и уже очень давно. Многие живут всю жизнь в ожидании газа и не дождавшись голубого топлива переезжают в другое место. Иногда газ проводят по границе деревни, но из-за того, что она уже числится нежилой, подвести голубое топливо в дома невозможно, даже

${ }^{1}$ Сообщество Костромская область. Социальная сеть vk.com. https://vk.com/wall-186602114_18184; https://manturovo.bezformata.com/listnews/o-gazifikatcii-v-manturovo/85889449/; Дойдёт ли газовая труба до Кологрива? Категория: Энергетика. https://okolo-griva.livejournal.com/28629. html; Сообщество «Подслушано Макарьев». https://vk.com/wall-92573238_98885.

2 Комментарии немного отредактированы, нецензурная лексика убрана. Подр. см.: https://vk.com/ wall-186602114_18184 (дата обращения: 22.10.2021). 
если есть желание. Так обстоит дело в д. Жиравлево Костромской области, Судиславского района. Газовая труба торчит на границе с участком одной из последних местных жительниц, но подключить дом нельзя. Частично из-за этого из деревни все жители уехали либо в областной центр, либо в населенные пункты, где есть газ и возможность подключения к нему. Конечно, это не единственная причина переезда жителей, но одна из главных.

Жен., 58 лет: «Вот у дочки родился сын, у нас холодина здесь. Топим дровами, воду надо натаскать из речки, нагреть. С маленьким ребенком думаете это так легко? Хочется жить так? А труба газовая вон торчит, а что толку? Так и переедем в другой дом, тут только летом еще можно жить. Грибов, ягод, трав пособирать. Дом жалко, даже за символическую цену не продашь, деревня уже никому не нужна. Дорог нет, воды нет, электричество вот разве что осталось пока. Так и его скоро не будет. А почему так произошло? Когда мы молодые тут заселялись деревня большая была. А сейчас работать негде. Молодежь вся работает в Костроме». Жительница эта долго не хотела покидать уже заброшенную деревню, но теперь они живут в другой деревне Судиславского раойна Костромской области, куда проведен газ.

Другой респондент из пгт Сусанино отметил, что после того, как в их поселение провели газ, мало что изменилось для жителей. Суммы для подключения личного хозяйства по местным меркам большие и недоступные, многие продают дома и покупают квартиры с уже имеющимся в них газом и коммуникациями или переезжают в город к взрослым детям. Это подтверждает и один из комментариев в сети «ВК» жителя пгт Судиславля: «Вы не спорьте, проведут вам газ или нет, а копите пока деньги. У нас тоже в Судиславле говорили, что газа долго не будет, но потом махом все сделали. Правда, мне пришлось два кредита брать, до сих пор плачу» (Подслушано Макарьев 2021).

\section{Уровень жизни в Костромской области}

Еще одним немаловажным фактором оттока местного населения является низкий доход семьи. Если зарплаты у ее взрослых членов на достойном уровне, то как показали наши исследования, люди возвращаются в родные места. Ярким примером является пос. Вохма Костромской области, где успешная политика местной администрации привела к возрождению производства, росту зарплат и, как следствие, к возвращению молодежи в район. При этом динамика социально-экономических показателей демонстрирует снижение реальных располагаемых денежных доходов населения в 2018 г. на $10 \%$ к предыдущему году и резкий рост безработицы в 2020 г. - в 7,3 раза. Необходимо отметить, что рост реальной заработной платы в процентном отношении к предыдущему 2017 году был незначительным - 10\% (Костромская область в цифрах 2020). По результатам нашего опроса и согласно статистическим данным в 2020 г. рост безработицы был рекордным, что отрицательно отразилось на благосостоянии костромичей. Более $60 \%$ экспертов в области межэтнических отношений подтвердило этот факт, правда в 2021 г. ситуация несколько стабилизировалась.

По оценке местной администрации, Костромская область по уровню доходов населения находится на 53-м месте в стране. Наше изучение независимых рейтингов, а также анализ официальной статистики показывают, что положение Костромской области с 2018 по 2021 гг. не изменилось. В частности, РИА-рейтинг ставит ее на 70 
место, а вот все остальные регионы ЦФО в основном находятся в середине списка.

Официальные предварительные отчеты сообщают, что среднемесячная номинальная начисленная заработная плата (без выплат социального характера) работников организаций Костромской области в январе-сентябре 2021 года составила 34130 рублей и увеличилась по сравнению с январем-сентябрем 2020 года на 9,6\%. Реальный размер заработной платы вырос на 2,6\% (О заработной плате 2021; Уровень жизни 2021). Как мы видим, в официальном отчете снова делается упор на хорошие и позитивные показатели. Отрицательная динамика почти не разбирается и не анализируется.

При этом результаты опросов говорят совсем о другой реальной средней заработной плате в Костромской области. По нашим оценкам, средняя зарплата в Костроме составляет 25 тыс., а в Костромской области - 15-20 тыс. рублей. Одним из маркеров уровня жизни основной массы населения негласно считается зарплата сотрудников образовательной и здравоохранительной сфер. Учитель истории в Костроме с 6 летним стажем за одну ставку получает около 20 тыс., с максимально возможной нагрузкой и 20 -летним педагогическим стажем, что бывает значительно реже - 35 тыс. (ПМА 2022). Согласно статистике РОССТАТА, средняя зарплата учителей Костромской области едва достигает 25 тыс. руб., для сравнения в Москве учитель получает около 95 тыс. руб., что почти в 4 раза больше (Зарплаты учителей в России 2021). Именно поэтому многие молодые учителя, приобретя опыт работы в школе, стремятся переехать в столичный регион, таких примеров нам известно немало. Это подтверждают и комментарии читателей статьи РОССТАТА, простых учителей. Например, Елена подробно описывает из чего формируется ее зарплата:

«08. 01. 2019 г. Карелия. Сельская малокомплектная школа. 25,5 ч. - 25 рабочих дней - 13 033,33 (сюда же классное руководство, проверка тетрадей и т.п.). Районный коэффициент (15\%) - 2842p., северный коэффициент (50\%) 9472 р. Стимулирование - почти 6000 р. (но его может и не быть, там на усмотрение местной власти, если есть деньги. Да и на самом деле, на такое симулирование работать тяжело. Овчинка выделки не стоит. Работы много, а стимула копейки). <..> Налог 4063 р. Итог: 31256 р. - 4063 р. = 27193 р. Это нагрузка за 50 часов в неделю».

А вот Соня, молодая учительница из Москвы при меньшей нагрузке имеет аналогичный доход: «Я аспирантка МГУ, по совместительству преподаю в школе для одарённых детей (Москва), 6 часов в неделю (химия). Получаю 25 000 в месяц».

Еще один участник дискуссии Виталий описывает доход своей жены в Костроме:

«У меня жена учитель. 25-30 тысяч в месяц зарабатывает, но это с учетом классного руководства и часовой нагрузки 40 часов в неделю, каждый день допоздна на работе. А я как знаю, штаткой считается 18 часов в неделю, так вот у нее получается больше 2-х штаток идет, и предметы все ведет - историю, обществознание, религию, географию и биологию, потому что в школе нет ни географа, ни биолога. <..> Мой знакомый (профессор) 3 должности при этом еще занимает (профессор кафедры + заведующий кафедрой + декан факультета) и на работе живет, так вот зарплата 42 тысячи (сам видел). А на государственных предприятиях все также плохо. Еду утром в лифте и вижу 2 объявления рядом. На одном на государственное предприятие (кстати одно из крупнейших в России) требуется слесарь по ремонту кранов ЗП - 20 тыс. руб., 
инженер-конструктор ЗП - 22 тыс. руб., а рядом висит объявление в кондитерскую требуется повар ЗП 40 тыс. руб., кондитер 35 тыс. руб., посудомойщик 20 тыс. руб. Так вот и делай выбор, либо пойдешь учиться на слесаря по кранам, а это необходимо образование на профессию минимум среднее-специальное, опыт работы т.к. при работе на кранах идет минимальный 5 разряд и допуск работы на высоте (удостоверение верхолаза), или преподавателем в институт (предварительно закончив аспирантуру и докторантуру), чтобы хотя-бы те же 20 тыс. руб. отбить, либо посуду мыть» (Зарплаты учителей в России 2021).

Независимый источник РИА-рейтинг зарплат 2020 г. подтверждает наши выводы о низком доходе местного населения. Он показывает, что область по уровню заработной платы занимает 65 место из 85 регионов. По подсчетам специалистов доля трудоустроенных с зарплатой выше 100 тыс. рублей составляет всего 1,6\%, а доля людей, работающих с зарплатой ниже 15 тыс. равна 18,5\%. Для сравнения в соседней Ярославской области доля тех, кто получает больше 100 тыс. - 2,1\%, а ниже 15 тыс. - 13,4\%, но в целом ситуация укладывается в общероссийскую картину (РИА зарплаты 2020).

Другой аналитический рейтинг зарплат по регионам, исключающий большие города, был также составлен агентством РИА. Им была подсчитана средняя заработная плата в малых городах, деревнях и селах. Выяснилось, что Костромская область по этому показателю оказалась на 63 месте (из 85). Судя по подсчетам экспертов, средняя зарплата в малых населенных пунктах региона - 28 тысяч рублей, но не медианная (т.е. та, которую получает большинство, а именно средняя). При этом соотношение реальной зарплаты с ценами на еду и услуги оказалось очень низким, что говорит об одном - на эти деньги местные жители не могут купить многие вещи (Зарплата 2021). Расчёт медианной зарплаты (т.е. реальный доход большинства) показывает еще более скромную сумму, которая едва ли превышает 15 тыс. рублей. Согласно данным наших массовых опросов 2021 г., которые были проведены в малых годах области, последняя указанная цифра подтверждает наши предположения, как и мониторинг сайтов вакансий Костромской области. Например, в колхозе им. Чапаева в Поназырево требуется доярка «осуществлять ручное доение коров с продуктивностью до 3,5 тыс. кг. молока в год и выполнять мероприятия по улучшению содержания животных» с окладом 12792 руб. (JobFilter 2021). В Костроме такой специалист получит уже от 20-25 тыс. руб., что тоже существенно ниже среднестатистического заработка в областном центре (Там же) $)^{1}$.

Как видно из результатов нашего опроса в 2021 г., многие жители в целом довольны своим материальным положением, но почти 40\% отметили, что испытывают материальные трудности, из них 10\% считают свое материальное положение тяжелым. Напомним, что в 2019 г. только 15\% посчитали, что их материальное положение затруднительно, а тяжелым назвали всего $3 \%$.

Эта ситуация на наш взгляд характерна для всей России в целом. По Костромской области можно судить как об экономике РФ, так и об уровне жизни простого населения по всей стране, потому что ситуация отражает действительный уровень жизни большинства ее граждан. В связи с этим, как неоднократно отмечали ученые ИЭА РАН, изучение межэтнической обстановки в регионах жизненно необходимо, поскольку население выживает и ждет помощи от государства, которая зачастую

\footnotetext{
${ }^{1}$ Средняя зарплата по данным Костромастата за первое полугодие 2021 г. составила 33749 и по сравнению с августом 2020 г. увеличилась на 11,5\%.
} 
приходит очень поздно. А приезжие, получающие блага наравне с местными жителями, а порой и раньше, в силу обладания статусом малоимущих и многодетных, воспринимаются часто как прямая угроза существующему бытию. Именно поэтому этнологический мониторинг, а также независимая экспертиза позволят быстрее и правильнее реагировать в экстренных ситуациях.

\section{Отношение местных жителей к мигрантам}

В 2021 г. в рамках проекта РФФИ нами было проведено 4 опроса в Костромской области: в гг. Кострома, Солигалич, Чухлома и Нерехта, причем по последним трем городам получены уникальные данные, на основании комментариев местных жителей отражающие жизнь российской глубинки. Необходимо отметить, что опросы в этих городах проходили с большим трудом, люди не хотели давать оценку своему социально-экономическому положению, выяснение которого входило в задачи нашего исследования. Большинство населения сейчас запугано властями. Ситуация в ходе опроса особенно обострилась в Нерехте, потому что прошел слух о «московском анкетировании» и власть пригрозила увольнением при «неправильном» ответе на вопросы и плохих показателях, из-за чего количество участников резко снизилось.

В опросе приняло участие 800 чел., в каждом городе было опрошено по 200 чел. Согласно выборке, описанной в инструментарии, 75\% респондентов были в возрасте от 30 до 59 лет, 15\% - в возрасте 18-30 лет, 10\% выборки представлены людьми пенсионного возраста. По этнической принадлежности $95 \%$ респондентов русские, $55 \%$ имеют среднее специальное, специальное и основное общее образование, $40 \%$ высшее и 5\% неоконченное высшее, 76\% участников опроса трудоустроены, $10 \%$ занимаются ведением домашнего хозяйства, 7\% безработные или самозанятые (официально не трудоустроены или имеют нелегальный доход).

Главной трудностью по мнению жителей области в общении с мигрантами является незнание языка (56\%), около $10 \%$ жителей региона раздражает несвойственное поведение приезжих, в основном отмечается их шумность, крикливость (громкие разговоры и смех) в общественных местах и в транспорте и только треть опрошенных $(33 \%)$ не испытывают никаких трудностей. При этом 80\% участников опроса почти не взаимодействуют в повседневной жизни с мигрантами, четверть из них не имеет никаких контактов с ними и только $15 \%$ имеют в основном разовые, эпизодические контакты с приезжими. У большинства респондентов (50\%) основное общение происходит при обслуживании в магазинах, в такси или общественном транспорте и др. В деловой сфере или по рабочим вопросам с мигрантами взаимодействует примерно 40\% участников опроса, которые как мы уже сказали носят эпизодический характер.

Одним из спорных показателей нашего исследования стал вопрос о трудоустройстве мигрантов и их участии на рынке труда. Здесь мнение респондентов разделилось, но большинство считают, что нет заинтересованности у костромичей ${ }^{1}$ работать на тяжелых физических работах, где зарплаты намного выше средних по региону. При этом уровень социального напряжения, подсчитанный по методике ИЭА $\mathrm{PAH}^{2}$, указывает на неготовность 90\% жителей к приезду мигрантов и к увеличению их ко-

\footnotetext{
${ }^{1}$ Под костромичами авторы статьи имеют в виду жителей Костромской области в целом.

${ }^{2}$ Автор и разработчик к.и.н., в.н.с. ИЭА РАН В.В. Степанов.
} 
личества в повседневной жизни. К тому же выявлена закономерность: «Чем дальше от областного центра, тем менее терпимым становится население».

Осознание нужности и важности труда приезжих у жителей области есть, т.к. $80 \%$ считают, что без труда мигрантов жизнь в Костромской области станет еще хуже. Костромичи готовы к тому, что мигранты будут работать в сфере ЖКХ, строительстве, дорожных работах, сельском хозяйстве или в личных подсобных хозяйствах. Самое удивительное, что население не готово в целом к увеличению количества водителей общественного транспорта из числа приезжих мигрантов (с этим утверждением согласилось только 10\%).

Вместе с тем, по статистике в изучаемый регион мигранты приезжают с целью обоснования и интеграции в российское общество, а не только заработать. Согласно официальной статистике в 2021 г. в область приехал 1207 чел., в т.ч. из стран СНГ 1022 чел., а по общему числу приехавших мигрантов Костромская область занимает предпоследнее место в ЦФО (Социально-экономическое положение 2021). Исходя из приведенных данных этого источника, можно заключить, что для мигрантов Костромская область не является привлекательной, потому что конкуренция с местным населением на рынке труда очень высока. Но сами иностранцы предпочитают обосновываться в малых городах на постоянное место жительство, чувствуя их особую привлекательность и меньшую угрозу для себя. Об этом упоминали и сами мигранты в личных беседах, что город очень красивый, старинный, небольшой, жизнь здесь спокойнее и не так «суетливо», как в Москве. Адаптироваться в такое общество гораздо проще, многие из них проводили аналогии с Родиной (ПМА 2019, 2020, 2021).

Еще одним важным вопросом был вопрос о преступности, которая, как часто считают, увеличивается с приездом мигрантов. Согласились с этим мнением 13\% респондентов, а 25\% затруднилось ответить на этот вопрос, но комментируя свое мнение отмечали следующее: «Сложно сказать, неоднозначное соотношение», «Зачастую мигранты оказываются не социализированы в новой среде жительства. Вследствие этого, большая часть преступлений (например, в Москве) совершается ими. Очевидно, что в этом плане политика социализации мигрантов, проводимая государством, провалена» (ПМА 2021). Вместе с тем, полевые данные за предыдущие годы указывают на большое недоверие к приезжим людям. Многие считают, что они распространяют наркотики, обманывают русских женщин/девушек и используют последних для получения гражданства. Последний фактор подтверждает вопрос о готовности принять в свою семью мигранта. Отрицательно к этой идее отнеслось $42 \%$ респондентов, затруднились ответить $26 \%$, нейтрально восприняли эту идею $25 \%$ и только 4\% - положительно. Похожий анонимный опрос был проведен администрацией города в 2014 г., когда 55\% костромичей посчитали межэтнический брак «кошмарным», но при этом 70\% участников отнесли себя к категории «толерантный» (Чиновники 2014). Получается, что за 7 лет ситуация почти не изменилась и отношение местных жителей к приезжим не улучшилось.

Другой вопрос, касающийся публичного выражения своего отношения к мигрантам, затрагивал вероятность участия в пикетах, митингах и демонстрациях. Он показал, что $55 \%$ не выйдет на улицу против иностранных граждан. Вместе с тем 35\% респондентов затруднились ответить на этот вопрос и сказали, что все зависит от тематики митинга, но если будут серьезные нарушения закона РФ, то обязательно выступят в поддержку этой инициативы. Также $67 \%$ высказалось за идею информирования вновь прибывших 
и уже проживающих в области мигрантов о существующих культурных нормах общества. За интеграцию высказалось около 57\% респондентов. Вместе с тем, 30\% не видят в этом большой необходимости, а еще $15 \%$ затруднились ответить. Вопрос о поддержке государством вновь приезжающих мигрантов и возможности помогать им тоже стал также неоднозначным. Многие сомневались и большинство отрицательно отнеслись к этой идее, что указывает скорее на материальные трудности и потребности в такой поддержке своих семей, ведь большинство живет весьма затруднительно, именно поэтому материальный аспект воспринимается негативнее всего.

\section{Портрет мигранта}

В нашем исследовании мы попросили участников опроса описать образ мигранта, каким его видят жители областного центра и малых городов. Это было одним из самых сложных заданий и вопросов анкеты, которое наши респонденты успешно выполнили. Для большинства это человек, гражданин другого государства, приехавший на заработки в нашу страну, выходец из бывших стран СССР, нерусской внешности, иной веры, плохо говорящий и понимающий русский язык. Мнения о человеческих качествах также разделились, из положительных указывалось трудолюбие, законопослушность и готовность к любому виду работ. Но были и отрицательные портреты: хам, нарушитель порядка, неквалифицированный специалист, паразит, неграмотный человек, варвар.

В соответствии с задачами проекта, респондентов просили назвать положительные качества мигранта. Вот наиболее распространенные среди них: «трудолюбие, скромность, работоспособность, сплоченность, вежливость и доброжелательность, готовность помочь, стремление и усидчивость, терпение, ответственность, мало пьют, мобильность, жизнелюбие, юмор, отношение к детям». Большинство отмечали именно трудолюбие и желание выполнять любые виды тяжелых работ, также многие хотели бы видеть его послушным и готовым в прямом смысле на все и не требующим ничего взамен. Немало оказалось и тех, кто затруднился ответить на этот вопрос (40\%), но «затруднилась ответить» эта часть респондентов не потому, что вопрос был сложен для них, а потому, что не смогли найти для себя положительных черт мигрантов, акцентируя на негативных моментах общественных контактов. Приблизительно 10\% ответило, что ничего не видят положительного в мигрантах.

Отдельная часть этого эксперимента касалась мнения респондентов о негативных чертах мигранта. Вот наиболее распространенные комментарии респондентов к портрету приезжего: «не уважает местные традиции», «не соблюдает гигиену», «ничего хорошего», «плохо говорит по-русски», «не знают языка», «неопрятны», «их слишком много стало везде», «они не знают российских законов, живут по понятиям, которые граничат с наглостью», «склонность к криминалу». В связи с выявлением в ходе исследования не всегда толерантного отношения к мигрантам мы задались вопросом, почему у костромичей сформировался такой портрет представителей других народов? Для анализа мы прибегли к мониторингу местных СМИ на предмет выявления оскорбительных маркеров в представлении образа мигрантов. Мы взяли наиболее распространенные новостные сайты в Интернете и проверили базу новостей, используя этнические маркеры: гастарбайтер, мигрант, этносы.

Как выяснилось, основная часть опасений, на которые ссылались респонденты в 
личных разговорах, была получена ими из статьей и новостей СМИ. Журналистами в публикациях, к сожалению, всячески подчеркивается, что представители других этносов несут угрозу. Вот, например, один из недавних заголовков: «Цены снижаются, мигранты разбегаются...». А дальше автор пишет, что «уважаемые» источники опубликовали сразу «две хороших» новости: о снижении количества «мигрантов-гастарбайтеров» и росте цены на патент для иностранцев. Т.е. получается, что костромичам надо радоваться отсутствию иностранцев в городе. Мы сделали небольшую подборку заголовков, которые показывают, какой образ мигранта рисуют местные СМИ: «Братья-гастарбайтеры устроили крупный героиновый бизнес в Костроме»; «У мигрантов в Костроме врачи обнаружили ВИЧ, сифилис и туберкулез»; «Таджик получил условный срок за нападение на костромичку»; «Иностранный любовник забил кормящую мать на глазах ее детей»; «Молодого узбека осудили за убийство на пилораме»; «Мигрант бросил торговать сухофруктами ради наркобизнеса в Костроме»; «Хитрый мигрант пытался разжалобить полицейских слезливой историей»; «Задержанные в Костроме наркоторговцы “топили” за ЗОЖ. Два брата-гастарбайтера не употребляли ни наркотики, ни алкоголь, занимались спортом - но не чурались травить героином других» (ГТРК Кострома; klnews.ru и др.). Если прочитать все эти заголовки, то вряд ли сложится положительное мнение о приезжих у местных жителей. И властям необходимо задуматься об организации семинаров для обучения межэтнической этике местных журналистов с приглашением опытных экспертов, которые смогут повысить уровень их толерантности и усилят понимание тонкости межэтнической темы.

Справедливости ради необходимо отметить, что за последний год количество и качество этнических маркеров заметно изменилось, теперь провинциальные СМИ более осторожно высказываются о мигрантах и лицах неславянской внешности. Но и полностью толерантными их назвать нельзя. Вместе с тем очевидно, что СМИ существенно влияют на межэтнические отношения и формирование портрета приезжих у местных жителей, поскольку уровень недоверия к ним высок. Причем по нашим исследованиям, чем дальше от мегаполисов и глубже в Россию, тем восприятие мигранта более негативно или максимум нейтрально. Например, по опросам в малых городах (Нерехте, Солигаличе и Чухломе) получилось, что местное население не хочет видеть мигрантов в своей повседневной жизни на равных, а если это присутствие неизбежно, тогда они не должны разговаривать на своем языке (а если и говорить, то только шепотом), вести себя тихо, не показывать своей национальной принадлежности, много работать на тяжелых работах, не получая никакой поддержки от налогоплательщиков. В Костроме население настроено более толерантно, но в целом ситуация очень похожа и если изучать ее более обстоятельно, то возможно в определенном социальном срезе обнаружится аналогичная картина.

Например, по словам работника миграционного центра, в 2022 г. произошла резонансная ситуация с убийством 5-летней девочки, видеокамеры зафиксировали как двое мужчин подхватили ребенка и унесли в неизвестном направлении. На видеокамерах было непонятно, кто именно подхватил девочку и поэтому в социальных сетях начинался бунт, носящий межэтнический характер, но потом личности преступников были установлены, что успокоило бунтовщиков и зачинщиков. Надо отметить, что действия властей по устранению разжигания межэтнической розни были сделаны вовремя, несмотря на праздники. Но этот случай показал, что в обществе продолжает существовать межэтническое неприятие, хотя и латентного характера, и 
возможно те, кто указал в ответах, что не стал бы выходить на митинги, просто не учли всех обстоятельств, а острая и резонансная ситуация с этническим маркером легко могла бы вылиться в массовый протест и потасовку.

В связи с этим необходимы действенные профилактические меры и регулярная работа с местным населением не только фестивального характера. Нам видится возможным более активное привлечение СМИ, создание специальных телевизионных передач, благодаря которым жители региона могли бы знакомиться с традициями и культурой других народов. Вероятно, имеет смысл привлекать самих мигрантов к участию в этих проектах, чтобы они делились историями своей жизни. Важно знакомить их с культурой принимающего сообщества, устраивать семинары и лекции ознакомительного и обязательного характера с профессионалами и квалифицированными специалистами, понимающими суть проблемы и готовыми работать в этом направлении. Необходимо привлекать и учителей области, которые бы на уроках истории, окружающего мира, обществознания, основах религиоведения разбирали темы межэтнического взаимодействия и толерантности, задавали реферативные задания, привлекали в том числе и старшего поколение. Нам видится необходимой разработка специального курса «Народы России» для объяснения молодым поколениям россиян правовых основ и принципов равноправия. Такие знания нужны, поскольку иногда под иностранными мигрантами в Центральной России местное население воспринимает представителей других народов, исконно проживающих на территории РФ (чеченцы, ингуши, кабардинцы, ногайцы, чукчи и пр.).

\section{Рекомендации (вместо выводов)}

Результатом нашего исследования стали рекомендации, которые, как нам представляется, могли бы быть полезны в повседневной работе органов государственной власти.

1. Потребность в привлечении дополнительных трудовых ресурсов во многом связана с общим неблагоприятным социально-экономическим и демографическим состоянием регионов России, особенно центральной ее части, которая в следствие длительного экономического упадка и естественной убыли населения испытает острый кадровый дефицит и тем самым привлекает иностранцев не столько для временного заработка, сколько для постоянного проживания. Продолжается перманентное сокращение населения. Например, в Костромской области только с 2018 г. численность жителей уменьшилось под воздействием различных факторов на 20 тыс. человек. Для преодоления негативных тенденций требуется целый комплекс социально-экономических решений, которые не приведут к сиюминутным изменениям и потребуют, возможно, десятилетий последовательной реализации их в жизнь.

У нашей страны есть позитивный опыт адаптации и интеграции населения, гармоничного проживания и развития множества народов и культур. Что касается исторического прошлого, на наш взгляд, одним из главных факторов успеха кадровой политики СССР была возможность получения бесплатного образования за счет системы распределения кадров, когда студент среднего профессионального или высшего учебного заведения должен был отработать в сельской местности или же в другом районе страны определенное время. 
Тем самым государство компенсировало затраты на обучение, а нуждающиеся районы получали квалифицированного специалиста. Конечно, многие уезжали в город после завершения обязательной отработки, но были и те, кто оставался и создавал на новом месте жительства семьи. Также студенты педагогических, медицинских, сельскохозяйственных институтов посылались на практику в школы, медпункты, больницы и хозяйства отдаленных деревень и сел. Многие таким образом возвращались к себе на малую Родину, кто-то проникался деревенской романтикой, а кто-то уезжал в другие республики $\mathrm{CCCP}$, чтобы познакомиться с новой культурой дружественных народов. Тем самым формировалось толерантное восприятие соседей, решались кадровые и социальные вопросы, сохранялись деревни и села России. При этом невысокие зарплаты компенсировались широкой помощью хозяйств молодым специалистам в быту и неизменностью цен на все товары.

2. Ныне существующая система ОГЭ и ЕГЭ наоборот, как показывают итоги нашего опроса, приводит к оттоку молодежи из сельской местности в города и желания возвращаться в родные места на низкие зарплаты, граничащие с нищетой, у молодежи нет. К тому же большинство потеряло возможность получить образование бесплатно. Даже в средние специальные учебные заведения стало попасть не так просто, к тому же несмотря на дефицит кадров в определенных отраслях, молодежь и не стремится идти туда за знаниями, потому что это тяжело и требует большого вложения сил (как умственных, так и физических). А многие не хотят получать образование, поскольку все реже оно требуется. Огромное количество курсов и коммерческих вакансий предлагают неплохой заработок, не требуют квалификации, опыта работы и знаний, поскольку заключают в себе нехитрые операции.

3. В связи с вышеперечисленными демографическими обстоятельствами необходимо обратить внимание местных властей, а иногда и стимулировать их со стороны федерального центра, на важность дополнительного привлечения иностранной трудовой силы. Иными словами целесообразно стимулировать региональные власти решать проблему нехватки трудовых ресурсов в значимых для жизни отраслях хозяйства за счет мигрантов, имеющих право или разрешение (патент) на трудовую деятельность. Сейчас же власти скорее относятся к внешней миграции как головной боли, от которой больше проблем, чем пользы.

4. Для преодоления «чемоданных настроений», то есть желания коренных жителей покинуть малый город или сельское поселение нужно отказаться от ряда проводимых реформ в социальной сфере и, прежде всего, от оптимизации школ, больниц и фельдшерских пунктов. Областные власти Костромы предпринимают определенные усилия для привлечения в регион врачей конкретных специальностей (узких), так и общей практики. Но это программа нуждается в расширении. Конечно, Кострома как областной центр во многом решила бы эту проблему с учреждением здесь медицинского института, как в соседних областных городах Иванове и Ярославле. В области также стоит остро проблема нехватки учителей начальных классов, преподавателей точных дисциплин (физики, химии, географии, а в некоторых школах даже математики). Вакансии, как правило, заполняются учителями-совместителями, а нагрузка на них дохо- 
дит до 40 час. в неделю, за счет этого качество обучения снижается. При этом финансовое распределение заработной платы не всегда бывает справедливым и не стимулирует качественный труд. Вообще надо радикально повышать оплату труда специалистов всех социальных заведений. Особенно неблагоприятна обстановка в сельской местности. Проблему нехватки кадров местные власти пытаются закрыть по программе «земский учитель». Но объявленные в этом году вакансии по конкурсу «земский учитель» имеют всего шесть (6) мест и это количество не может решить проблему такого большого региона.

5. Опросы населения в малых городах показали, что народ надеется на помощь от государства в открытии новых производств, создании птицеводческих фабрик, небольших производств в фермерских хозяйствах в глубинке, в т.ч. в Солигаличе и Чухломе (175 км на север от Костромы). Радикальных изменений требует инфраструктура жилья, включая необходимость проведения коммуникаций, газификацию, что реально бы улучшило жизнь людей, социальное самочувствие провинциального общества, условия проживания в целом. Эти меры важны и потому, что пока еще остаются не потерявшие навык тяжелого сельскохозяйственного труда и желающие им заниматься представители среднего и старшего поколения. Крестьянина, как известно, не подготовишь в профтехучилище или сельхозтехникуме. Постоянный труд, любовь к природе и к «братьям нашим меньшим» - это образ жизни. И здесь, на наш взгляд, государство могло бы пойти на поддержку создания (возрождения) утраченных за годы революции и советской власти сельских приходов, службы священников и в целом приходской жизни, что-то наподобие программ «земский врач», «земских учитель». Все это будет укреплять традиционные духовные скрепы в России, повседневную жизнь семей с целью и сохранения, сбережения, а потом и возрождения народа.

6. Ключевым моментом адаптации мигрантов в российское общество является знание приезжими из стран ближнего зарубежья русского языка. Поэтому важно не только готовить в этих государствах кадры востребованных в России профессий, но и поддерживать знание языка для соответствующей возможности беспроблемного общения в магазине, на транспорте, местах массового пребывания. Безусловно надо создавать специальные центры для переподготовки кадров на уровне регионов (областных центров). Важно чтобы эти центры имели связь со всеми местами пребывания и объектами производства в регионах (в том числе районными городами и поселениями), чтобы была регулярная информация по всем вопросам взаимоотношений мигрантов и местных русских жителей.

7. Многие правильные законы и нормативные акты по проблеме миграции уже приняты, но требуют переосмысления. Так еще в 2008 г. принят закон «О государственной геномной регистрации». Следовательно, надо проанализировать практику применения этого закона в разных регионах, а все выявленные недостатки устранять в повседневной работе с тысячами мигрантов, пребывающих в регионах России. Надо изучить принятые законы и, если необходимо, внести изменения в них в соответствии с опытом и практикой применения.

8. Еще одной проблемой, которая характерна для мегаполисов (Москва, С.-Петербург) и городов с миллионным населением (Н.-Новгород, Самара, Ростов-на-До- 
ну и т.п.), где контроль за миграционной средой, как правило, переложен, на плечи силовых структур (МВД, Росгвардия) заключается в отсутствии профилактической работы с этническими диаспорами, либо о ней мало кто знает. Между тем мигранты в России представляют традиционные восточные общества, где силен авторитет главы семье, племени, рода-тейпа. И если правильно выстроить отношения с ними можно предотвращать преступления силами самих мигрантов, поставить под контроль значительную часть времени жизни мигрантов, связанную не с производством, где они все на виду, а со свободным временем, досугом. Конечно, важно не допускать формирования многотысячных этнических поселений (наподобие «Садовод» или Фут Сити), добиваясь разукрупнения таких поселений и внятного постоянного контроля, в том числе за деятельностью ОПГ. Здесь также важно поставить административный предел росту мегаполиса со стороны властей Москвы.

9. Необходимо учитывать позитивный опыт отдельных регионов и распространять его. В чем состоит позитивный опыт областного центра города Костромы? Здесь, опираясь на старшее поколение мигрантов - выходцев из стран СНГ и ближнего зарубежья, в частности Таджикистана, удалось сплотить основных представителей миграционного сообщества вокруг «объединенной среднеазиатской общины». Всякое положительное начинание держится на конкретных людях. Так в Костроме в поисках лучшей жизни появился спортсмен из Таджикистана Сергей Вячеславович Хусаинов. Со временем ему предложили представлять культуру таджикского народа в костромском регионе. Постепенно в общину стали обращаться представители других народов, проживающие в Костроме. Поэтому совет старейшин принял решение объединиться с ними, и все проблемы стали решать сообща. Целями общины в настоящее время являются задачи сохранения межнационального и межконфессионального согласия на территории Костромской области, интеграции и адаптации пребывающих мигрантов, преодоления языкового барьера, разрешения юридических вопросов. Трудовых мигрантов знакомят с историей, культурой и традициями жителей Костромского края. На эти цели были выделены городские и областные гранты. Но таких организаций мало в других городах России, а там, где они есть случается противодействие таким общинам. Именно поэтому необходимо организовать тесное взаимодействие местных органов власти с общественными организациями мигрантов для более успешной адаптации людей и профилактики правонарушений. В противном случае пропадает желание у них жить в данном городе, успешно адаптироваться и встраиваться в общую с местным населением повседневную жизнь. Положительный опыт работы с диаспорами в небольших по численности областных центрах можно использовать в других городах, в том числе в столице. Надо сформировать в хорошем смысле пирамиду управления: город районы - отдельные общины мигрантов. Сейчас же работа с общественными организациями во многом напоминает фестивально-выставочную витрину, которая имеет сомнительное отношение к профилактике экстремизма. 


\section{Источники и материалы}

Старостина Ю. Пандемический криз. Как скоро экономика России сможет вернуться к росту. ГАЗЕТА № 093 (3260) (1711) от 17 ноября 2020. РБК: https://www.rbc.ru/newspaper/20 20/11/17/5fabc9289a79476ec20f16cc.

Росстат 2010 - Росстат. Всероссийская перепись населения 2010 г.

Костромская область в цифрах 2021 - Костромская область в цифрах. Стат.сб./Костромастат. - К., 2021. - 117c. kostroma.gks.ru.

Кузнецов, Уханков 2019 - Кузнецов Д., Уханков А. «Типичный депрессивный регион». С чем Костромская область отмечает свое 75-летие. https://7x7-journal.ru/articles/2019/08/15/ tipichnyj-depressivnyj-region-s-chem-kostromskaya-oblast-otmechaet-svoe-75-letie.

Мишустин 2020 - Мишустин заверил, что власти будут делать все для решения проблем в регионах. Агентство TACC. https://tass.ru/ekonomika/7972163 (дата публикации: 13.03.2020).

Жители района 2021 - Жители района Костромской области умоляют Путина провести им газ. https://logos44.ru/zhiteli-rajona-kostromskoj-oblasti-umolyayut-putina-provesti-im-gaz. html (дата публикации: 18.05.2021).

Газификация 2021 - Газификация Костромской области. http:/gkh.adm44.ru/stroy/gazko/ (дата обращения: 10.12.2021).

О газификации 2020 - О газификации в Мантурово. Заместитель главы администрации городского округа город Мантурово по ЖКХ А.Д.Блохин. https://manturovo.bezformata.com/ listnews/o-gazifikatcii-v-manturovo/85889449/ (дата публикации: 24.07.2020).

Костромские депутаты 2021 - Костромские депутаты предлагают использовать маткапитал для газификации. https://regnum.ru/news/economy/3392968. html (дата публикации: 8.10.2021).

Подслушано Макарьев 2021 - Подслушано Макарьев. https://vk.com/wall-92573238_98885 (дата публикации:25.04.2021).

О заработной плате 2021 - О заработной плате в организациях Костромской области в янваpe-октябре 2021 г. https://kostroma.gks.ru/folder/26037; https://kostroma.gks.ru/folder/79874/ document/147138 (дата публикации: 23 декабря 2021 г.);

Уровень жизни 2021 - Уровень жизни. Оперативная информация. https://kostroma.gks.ru/ folder/26037 (дата публикации: 23 декабря 2021).

Зарплаты учителей в России 2021 - Зарплаты учителей в России. https:/visasam.ru/russia/ rabotavrf/zarplata-uchitelya-v-rossii.html\#__2021 (дата публикации: 27.12.2021).

РИА зарплаты 2020 - Рейтинг российских регионов по уровню зарплат - 2020. https://ria. ru/20201123/zarplata-1585826589.html (дата публикации: 23.11.2020).

Средняя зарплата по данным Костромастата за первое полугодие 2021 г. составила 33749 и по сравнению с августом 2020 г. увеличилась на 11,5\%.

Социально-экономическое положение 2021 - Социально-экономическое положение центрального федерального округа в январе-сентябре 2021 года. Москва: РОССТАТ, 2021. С. 46. https://rosstat.gov.ru/storage/mediabank/cent_fo3.pdf.

Чиновники 2014 - Чиновники хотят узнать правду о межнациональных отношениях. https:// k1news.ru/news/society/kostromichi-schitayut-chto-braki-s-inostrantsami-eto-koshmar/ (дата публикации: 26.12.2014).

Костромская область в цифрах 2020 - Костромская область в цифрах. Стат.сб. / Костромастат. Кострома: Территориальный орган Федеральной службы государственной статистики по Костромской области (Костромастат), 2020.

\section{Научная литература}

Мартынова М.Ю. Толерантность и культурная традиция. М.: Изд-во РУДН, 2002.

Cтепанов B.B. Этнический и религиозный состав населения ПФО //Миграционная ситуация в регионах России. Выпуск второй: Приволжский федеральный округ / под общей ред. Ж.А. Зайончковской. М.: Институт народнохозяйственного прогнозирования РАН, 2004. 
Тишков В.А. Единство в многообразии: публикации из журнала «Этнопанорома» 1999-2008 гг. Оренбург: Издательский центр ОГАУ, 2008.

Тишков В.A. Этническое и религиозное многообразие - основа стабильности и раз-вития российского общества: Статьи и интервью. М.: Московское бюро по правам человека, "Academia", 2008.

Тишков В.A., Степанов В.В. (под ред.) Этнополитическая ситуация в России и сопредельных государствах в 2012 году: Ежегодный доклад. М.: ИЭА РАН, 2013. С. 144-150.

\section{References}

Martynova. M.Yu. 2002. Tolerantnost' i kul'turnaia traditsiia [Tolerance and cultural tradition]. Moscow: RUDN University Publishing House.

Stepanov, V.V. 2004. Etnicheskii i religioznyi sostav naseleniia PFO [Ethnic and religious composition of the population of the Volga Federal District]. In Migratsionnaia situatsiia $v$ regionakh Rossii. Vypusk vtoroi: Privolzhskii federal'nyi okrug [Migration situation in the regions of Russia. Second edition: Volga Federal District], edited by J.A. Zayonchkovskaya. Moscow: Institute for Economic Forecasting RAS.

Tishkov V.A., and V.V. Stepanov (ed.) 2013. Etnopoliticheskaia situatsiia v Rossii i sopredel'nykh gosudarstvakh v 2012 godu: Ezhegodnyi doklad [Ethnopolitical situation in Russia and neighboring states in 2012: Annual report]. Moscow: IEA RAN.

Tishkov, V.A. 2008. Edinstvo v mnogoobrazii: publikatsii iz zhurnala "Etnopanoroma" 19992008 gg. [Unity in diversity: publications from the magazine "Ethnopanoroma" 1999-2008]. Orenburg: Publishing Center OGAU.

Tishkov, V.A. 2008. Etnicheskoe i religioznoe mnogoobrazie - osnova stabil'nosti i raz-vitiia rossiiskogo obshchestva: Stat'i i interv'iu [Ethnic and Religious Diversity - the Basis of Stability and Development of Russian Society: Articles and Interviews]. Moscow: Moscow Bureau for Human Rights, “Academia”. 